\title{
Analysis of the Relationship Between Income Inequality and Poverty Prevalence in Selected North Central States of Nigeria: 1991 - 2013
}

\author{
Ndako Yahaya Shaba ${ }^{1}$, S. A. J. Obansa ${ }^{2}$, Sule Magaji ${ }^{2}$, Mohammed Yelwa ${ }^{2}$ \\ ${ }^{1}$ General Studies Department, The Federal Polytechnic, Bida, Nigeria \\ ${ }^{2}$ Department of Economics, University of Abuja, Nigeria \\ Correspondence: Mohammed Yelwa, Department of Economics, University of Abuja, Nigeria.
}

Received: October 30, 2017

doi:10.11114/aef.v5i3.3105

\author{
Accepted: March 2, $2018 \quad$ Available online: March 14, 2018 \\ URL: https://doi.org/10.11114/aef.v5i3.3105
}

\begin{abstract}
Poverty in Nigeria has been described as pervasive owing to the fact that the nation has witnessed a persistent increase in poverty level over the years despite various poverty alleviation programs. More so, it has been argued that income inequality is a manifestation as well as strong cause of poverty. The study therefore analyses the empirical relationship between income inequality and poverty prevalence among households in selected North Central States in Nigeria. This study employed survey method supported by time series data using regression analysis A representative sample of 600 respondents was planned for the survey in order to have at least 462 households responding. The result shows that dependency ratio, level of calorie intake, poverty per head counts are important factor influencing the level of poverty prevalence. Hence the study observes a substantial correlation between income inequality and poverty prevalence in the studied North Central Nigeria. The study therefore recommends a deliberate policy of reducing income inequality through equitable distribution of income and acceptable revenue sharing formula, need to campaign against large family size, providing subsidy and credit facilities for farmers and artisans true co-operatives, overhauling existing poverty alleviation programme and finally instituting good governance in every sphere of government activity which is a sine-qua-non for poverty reduction.
\end{abstract}

Keywords: poverty prevalence, income inequality, relative difference in income

\section{Introduction}

There has been a renewed and growing concern about increasing poverty and income inequality both within and across countries and their negative implications for both growth and social peace (Bourguignon, Fournier and Gurgand 1998; Birsall 2005).

In Africa, poverty remains a scourge that undermines development in contemporary African Society in that: it is deep-rooted and pervasive (Igbatayo\&Igbinedion, 2006). Perhaps, nowhere in the African continent is the scourge more prevalent than in sub-Saharan African, where about one-sixth of people are chronically poor (World Bank 1996, CFA, 2005).

In Nigeria, the twin's issue of poverty and inequality income distribution presents a paradox. This is so because, though the country is rich in land, human and natural resources, the people are still considered to be poor, as nearly 70percent of Nigerian in 199 were living in poverty (Soludo, 2006).

In the past few years, Nigeria government has spent colossal sums of money at various levels in vain attempts at reducing poverty by initiating and executing several poverty alleviation programmes. However, many of the programmes do not produce the desired result.

Studies have shown that poverty and income inequality are closely related (Ravallion 2009). More so, it has been argued that income inequality is a manifestation as well as a strong cause of poverty (UNU/WIDER. 2000). Income inequality is often studied as part of broader analysis covering poverty and welfare. Income inequality is detrimental to economic growth and development, because it aggravates poverty and that is why it is important to measure and monitor its level from time to time (Ugoh\&Ukpere, 2009).

From the foregoing, it became imperative that measurement and analysis of poverty and inequality are crucial for cognitive purposes, (to know what the situations is); for analytical purposes (to understand the factors determining this 
situations); for policy making purposes (to design interventions best adapted to the issue); and for monitoring and evaluation purposes (to assess the effectiveness of current policies; and to determine whether the situation is changing).

The paradox of the scenario is that while a privileged few Nigerians are living in affluence, majority are in the state of abject poverty: the poverty experience by Nigerians is pervasive, multifaceted and chronic, affecting the lives of a large proportion of the populace (Kudi, Usman, Akpoko\& Banta, 2008). In an extension of the paradox above, Nigeria's case is that of the rich country but poor people. This is captioned "Poverty in the midst of plenty" by the World Bank (World Bank, 1996).

North Central States in particular Kogi, Niger and FCT are not exempted from this challenge which has caused the states to continue to witness anti-social behavior from her teeming un-employed youths despite the enormous natural resources.

Apparently, the scenario has become increasingly worrisome particularly because poverty and income inequality are shown to have been closely related (UNU/WIDER, 2000, Kocenikov\&Shorrocks 2003). More importantly, poverty in Nigeria besides its being exacerbated by inequality in income is also seen to be essentially a rural phenomenon attributed to the majority who are located in the rural and engaging in agricultural production and allied activities.

Previous researchers have attempted similar work but with remarkable difference and limitations. Most work particularly in Nigeria focuses on income inequality and growth. It was against this background that this study was undertaken to investigate or otherwise to which income inequality exacerbate the incidence and or severity of poverty in North Central States, Nigeria

The broad objective of this study is to investigate the relationship between income inequality and poverty prevalence in selected north central states of Nigeria.

\section{Literature Review and Theoretical Framewrk}

\subsection{Conceptual Review}

\subsubsection{Concepts of Poverty and Income Inequality}

Poverty is one of the intractable problems facing mankind today. It has been estimated that at least 50percent of the poor in sub-Saharan Africa live in East Africa and Nigeria (Ilori, 1999). Poverty is a living conditions in which an entity is faced within economic, social, political, cultural and environmental deprivations to which a person, household, community or nation can be subjected. It is saddening that while the number of the poor in developed countries has reduced considerably over the years, the reverse is the case in many developing countries including Nigeria.

Poverty remains a multi-dimensional concept, as it does not lend itself to a single, universally accepted definition (UNECA, 2005). Hence literature is replete with definitions reflecting the peculiar perceptions of various researchers and policy makers, as well as the circumstances prevailing in different regions of the world (Igbinedion and Igbatoyo, 2007). For instance, many analysts conceive poverty in terms of individual or family insufficiency of assets and income. Atolaye (1997) and EnglamaBamidele (1997) conceptualized poverty as the "lack of basic necessities". Along this basic needs approach, poverty can be conceived of an absolute and relative poverty (UNDP, 1990).

Inequality on the other hand, implies the dispersion of a distribution whether one is considering income, consumption or some other welfare indicators or attributes. Although conceptually distinct, income inequality is often studied as parts of the broad analysis covering poverty and welfare. Thus inequality is a broader concept than poverty because it is defined over a whole distribution (Litchfield, 1999). The pattern of income distribution has been of great concern to Economists for a long time.

Many opinions believe that income and consumption levels say very little about standard of living. This is probably the reason why the 1990 WDR stressed the need to include other social factors such as health, life expectancy, accesses to clean water, education and so on. Engalama A \&Bamidele A (1997) summarized the definition of poverty in both absolute and relative terms. Poverty is defined as "a state where an individual is not able to cater adequately for his/her basic needs of food, clothing and shelter, meet social and economic obligations; lack gainful employment, skills, asset and self-esteem and has limited access to social and economic infrastructures such as education, health, portable water and sanitation and as a result has limited chance of advancing his/her welfare to the limit of his/her capabilities" (NES $141-150)$

Though there seems not to be a universally acceptable definition of poverty. Nweze\&Ojowu (2002) as well as Sachs (2005) opine that poverty can be categorized into three, namely: Absolute, Relative and Subjective. Absolute poverty deals with basic human needs measured by resources required to maintain physical efficiency (Haralambos and Heald, 1980; Kuper\&Kuper, 1996). However, relative poverty is a situation where an individual or a household's income is less than average income of the population in the society being considered. This means that the individual or household has goods and services which are lower than those of other persons or household in the country, state, community or society. 
Oladunni (1999). The concept of subjective poverty, "expressed in a range of non-material and intangible qualities: it is based on respondent's perception of their standard of living. The feeling of whether one is poor or not depends on individual/societies psychology.

However, poverty can be measured by identifying the poor and the aggregation of their poverty characteristics into an overall measure. Three of such overall measures include poverty line, profiles and indicators. In general, poverty lines provide the basis for measuring the poverty profile of a country while the poverty indicator serves as indirect measure.

\subsubsection{Concept of Income Inequality}

Inequality can be conceptualized as the dispersion of a distribution whether one is considering income, consumption or some welfare indicators, therefore, income inequality refers to how evenly or unevenly income is distributed in a society (Babatunde 2008). Income inequality is often studied as part of broader analysis covering poverty and welfare. As mentioned earlier, income inequality is detrimental to economic growth and development, because it aggravates poverty and that is why it is important to measure and monitor its level from time to time. Income Inequality can be measured using the Gini Coefficient and the regression based decomposition methods.

\subsubsection{Level of Poverty in Nigeria}

Before delving into the categories of poverty in Nigeria a nation naturally well endowed, one may ask "is there a poor man in Nigeria? However, according to Muhammad (2014) it is he who is contented that is he who is happy. How many Nigerians are truly contented not pretentiously contented? To him, every Nigerian is a potential wealth expectant because there is wealth everywhere within the shores of the country.

However, three levels of poverty are adduced from Nigerians. Firstly, there are those who are poor but do not believe that they are poor. For this group, they struggle sometimes by all means possible to find a way keeping their bodies and souls together. They are those begging on the streets; those unable to feed thrice a day with good meals; those unable to cater for their own children in terms of education, health and shelter; those languishing in the prisons for trivial offences.

The second categories are those who are not poor but believe that they are equal to the poor. This group is made up of the insatiable minds who will refuse to pay a laborer his paltry reward upon the abundance they swim in. They compete to be the greatest in wealth amassment which arithmetically translate to impoverishing more Nigerians. They are not limited to some politicians, including political prostitutes and sycophants; some businessmen and women; hardened criminals involving in bank robbery; pen robbery, 419, arm smuggling, kidnapping and bunkering.

The third categories are those who are neither rich nor poor and believed in what they are. These categories constitute an insignificant number of the Nigerian population.

\subsection{Trends in Poverty and Inequality in Nigeria}

Poverty among plenty is the world greatest challenge and the resurgence of interest in the issue derives from the effect that growth has on poverty. Economic growth which is accompanied by high inequality will have a lesser poverty-reducing effect than one which is inequality - neutral. It also follows that the decline in poverty incidence resulting from growth would be larger when accompanied by declining inequality.

However, Nigeria is also one of the most unequal societies in the world, with income distribution skewed heavily such that whenever aggregate growth occur, it is not shared by all. On the average, Nigerians are very income poor. But the skewed distribution of the available income makes the situation of the have-nots to be desperate.

Poverty and inequality are global phenomenon but the rates in Nigeria are higher than most countries in the world. Since 1980s, the poverty rate has been trending significantly downward in all regions of the world except in sub-Saharan Africa (SSA).

According to Bello (2007) 70 percent of the over 140 million Nigerian lived below the poverty line of US $\$ 1$ per day. Poverty has been on a continuous rise in the country. 


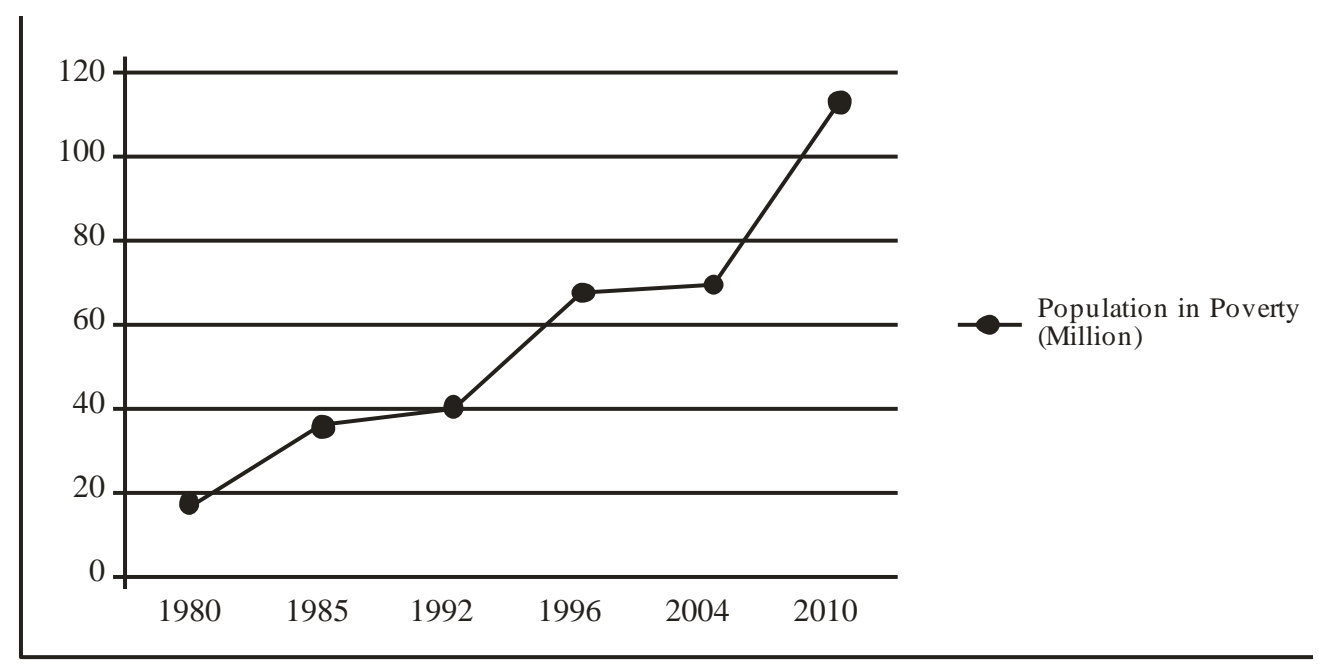

Figure 2.1. Nigerian Poverty Profile (1980 - 2010)

Source: (NBS, 2010)

The percentage of Nigerians living in poverty is growing. Poverty in Nigeria has substantially risen between 1980 and 2011. The proportion of the core poor have continued to increase overtime.

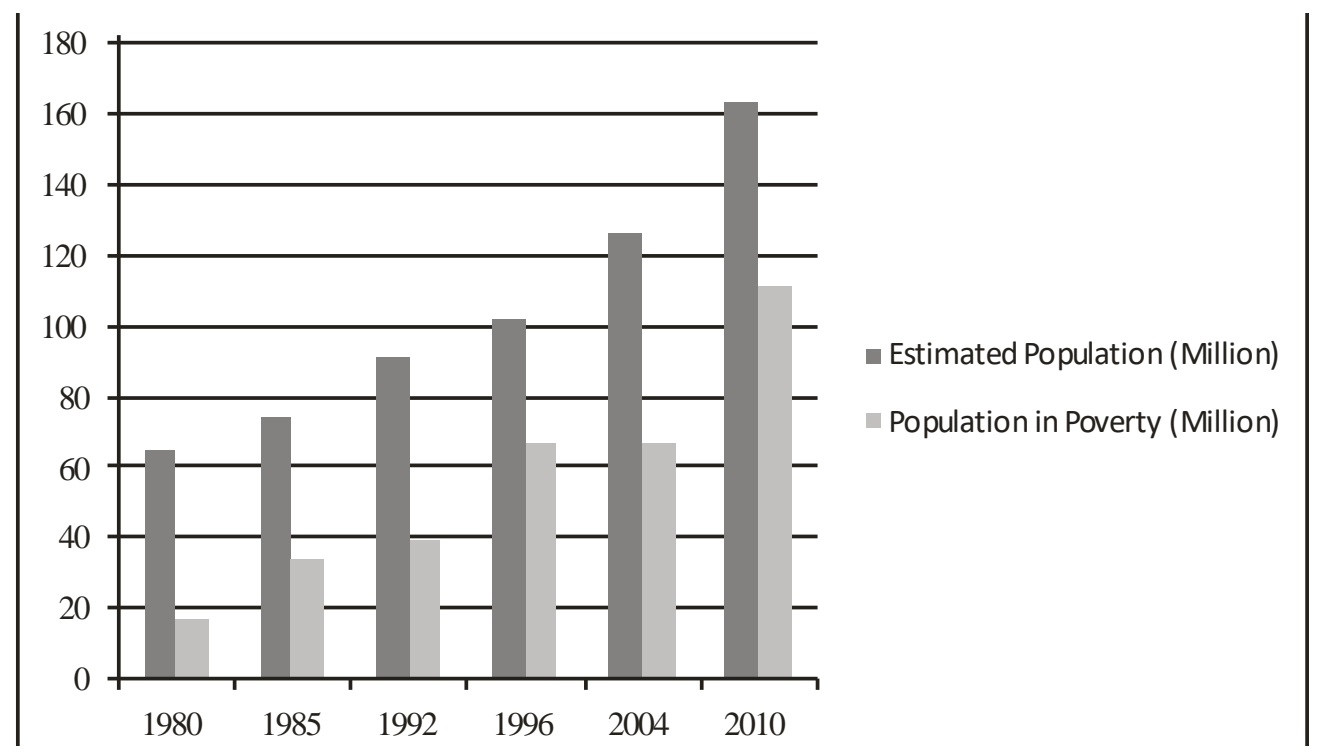

Figure 2.2. Nigerian Poverty Profile - Estimated Population versus Population in Poverty (1980 - 2010)

Source: (NBS, 2010)

Statistics also shows that inequality calculated by Gini coefficient rose consistently from 1985 except for a slight decline in 1992. At the national level, inequality declined from 0.43 in 1985 to 0.41 in 1992 and rose to 0.49 in 1996 . It decline to about 0.43 in 2004 and increased to approximately 0.45 in 2010 (NBS 2010).

According to the MPI report, as at 2010, 46 percent of Nigeria lived below the national poverty line with only 28 percent in urban areas, and nearly 70 percent in the rural areas.The report ranked the thirty-six states and federal capital territory according to incidence of poverty with Lagos state having the lowest poverty rate of 8.5 percent and Zamfara state with poverty rate of 91.1 percent. The national average rate of poverty in Nigeria stands at 46 percent. The regional averages shows that South West 19.3 percent, South-South 25.2 percent, South-East 27.36 percent, North Central 45.7 percent, North-East 76.8 percent and North-West 80.9 percent. 


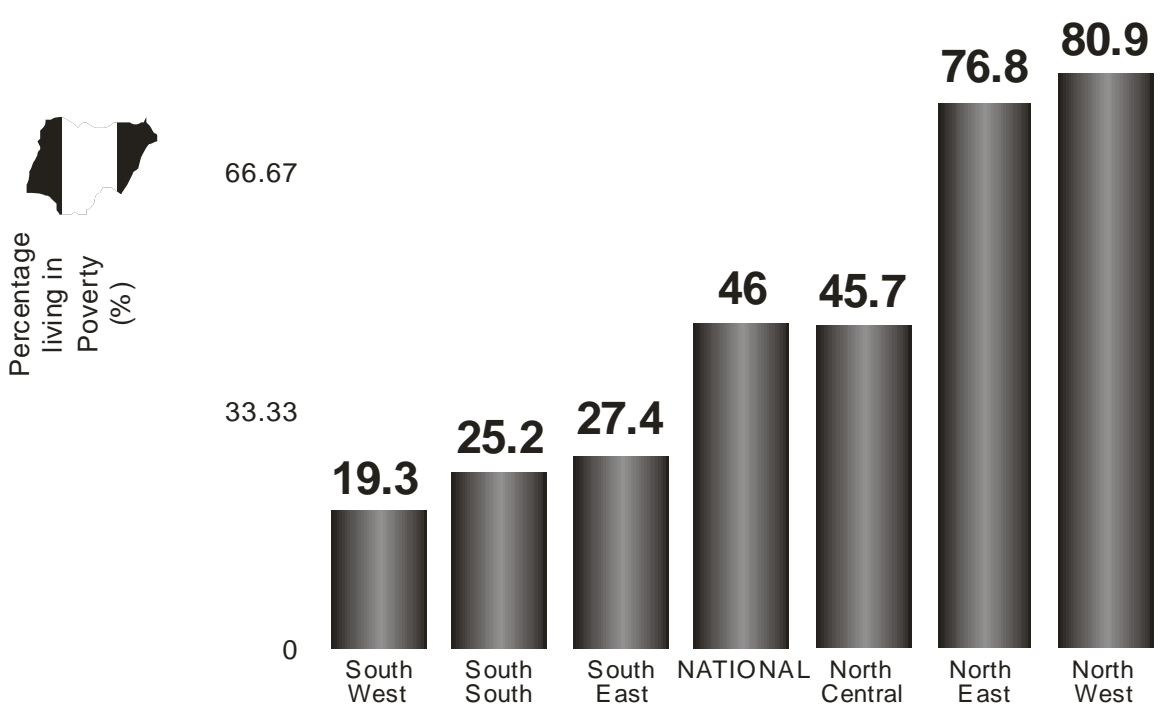

Figure 2.3. United Nations’ Multidimensional Poverty Index 2015

\subsection{Empirical Review}

Pigou (1912) and Dalton (1920), proposed a Pigou Dalton transfer. This principle opines that inequality increases when there is a transfer of income from a poorer to a richer person. More so, measure of inequality in literature satisfies this principle.

Furthermore, Dalton (1920), proposed the population principle of income inequality measurements which observe any equality measures are invariant to replications of the populations. This implies that merging two identical distributions will not alter the level of inequality.

Oyekale, et al. (2005) examined, "sources of income inequality and poverty in rural and urban Nigeria" they used the data from National Integrated Households' Survey collected by the Nigeria Bureau of Statistics (NBS) in 2003. The mean, standard deviation and coefficient of variation were used to measure income inequality vis-a-vis the per capita income, which is a measure of welfare. It was found that, income inequality is detrimental to economic growth and development and that income inequality is increasing in the rural and urban areas in Nigeria, which can be linked to the growing dimension of poverty.

Awe and Olawumi (2012) on Income inequality and growth showed that, Gini Coefficient in Nigeria is high i.e. an indication of a high level of income inequality. The study covered the period of 1977-2005 and employed a co-integration technique on employment rate, inflation rate, Gross Domestic Product (GDP) etc, using Gini Coefficient as an indicator variable. Furthermore it found that social spending were true determinants of income distribution in Nigeria.

\subsection{Theoretical Review}

While economists have theory of economic inequality, there is no theory of poverty in the conventional sense of the word (Akeke-Dolu-Ale, 1975). Rather, poverty theories are woven around the objects and subjects, as well as the nature of the phenomenon (Tella, 1997).

Just as there is not universally acceptable definition of poverty so it is with theories of poverty. However, there are so many theories of poverty depending on individual perspective and the nature of the phenomenon.the following are theories of poverty; the capitalist entrepreneurial theory, the conservative theories (individualistic and culture of poverty), the liberal reformist's perspective which deals with situational theory of poverty, the radical structural Marxist perspective also known as the power theory, the social exclusion theory, The national circumstantial theory, the modern theoretical approach

The modern theoretical approach however, considers the income dimension on the core of most poverty related problems. To this end, poverty according to modern theory may arise from:

i. Change in average income 
ii. Change in the distribution of income

Assuming a relationship between poverty line $(\mathrm{L})$ and the average income of the population $(\mathrm{Y})$, the poverty index will increase/decrease as $\mathrm{L} / \mathrm{Y}$ increases/decrease. So, the higher the average income is above the poverty line, certain, paribus, there will be less poverty. The theoretical foundation of this work is based on this theory.

\section{Methodology}

\subsection{Study Area}

Kogi, Niger and FCT. These states were chosen as the survey area because of its strategic geo-location together with its characteristics of high prevalence of poverty (NBS 2006).

\subsection{Sources and Method of Data Collection}

Both Primary and Secondary sources were employed for the study. That is both survey and time series data were used for the study. Questionnaire was administered in addition to secondary data covering $1991-2013$. The study is limited to this period because Kogi State and FCT was created in 1991, while Niger State was 1976.Due to the variation in the dates of the creation of states and area councils, the study decides to 1991 as the base year, been the last year for the creation of the states. Furthermore, 1991 was particularly chosen for comparative, collection of data and sound statistical analysis purpose.

\subsection{Sample Size and Sampling Technique}

Stratified Random Sampling Technique was employed in order to select about 462 respondents for the study at an equal rate of 154 respondents each state with a consideration of the three senatorial zones that makes up the state. Furthermore, four (4) Local Government Area (LGAs) for each senatorial zone of the state and six area council in FCT were considered Geographical location factor played a significant role in the choice of the local councils via each zone otherwise tagged on Urban and Rural Local Government. Other factors considered are accessibility to basic primary healthcare facilities, accessibility to portable water, rural electrification etc. This is in line with the studies of Chou (1969), Walpole (1974) and Obansa (2011).

\subsection{Method of Data Analysis}

The study made use of both descriptive statistics and regression analysis. However, before carrying out regression analysis on the time series data, various pre and post diagnostic tests were carried out the use of-JauqueBera for testing normality distribution of data and Co-integration for Stationarity Test became relevant.

\subsection{Model Specification and Estimation Procedure}

$P C I=\sigma 1+\sigma 2 \Delta$ incQ1Q4it $+\sigma 3 P C I t-1+\varepsilon$

$\Delta$ inc $Q_{1} Q_{4 i t}=\beta_{1}+\beta_{2}$ depratio $+\beta_{3} G P C f+\beta_{4} G P C f_{t-1}+\beta_{5} E d u+\beta_{6} C a l+\beta_{7} P h c+\varepsilon$

Given the above system of equation models; a two-stage least squares (2SLS) approach would be more applicable (Öjteg 2008). The above is also consistent with Waldmann (2009); ( Ukpong 1998 and Okunmadewa et al. 2005 etc)

Where;

$P C I=$ per capita Income a proxy of relative poverty

$\Delta$ inc $Q_{1} Q_{4 i t=}$ relative difference between the wages of lowest and uppermost quintiles

Depratio=dependency ratio of the household heads

$G P C f=$ Gross fixed per capita formation

$E d u=$ Education level of the household

Cal $=$ Calorie intake level

$P h c=$ Poverty Head count

$\varepsilon=$ usual error of the classical assumption

The choice of this technique was informed by the need to determine the time series characteristics of the variables that are employed on the economic estimates of the study.

\section{Discussion of Results}

This section presents the result and analysis of data collected from survey and time series data for the period of 1991-2013 for a sample of 501. 


\subsection{Socio-Economic Characteristics of yhe Population Under the Study}

The data employed in this study constituted mainly of primary data from survey conducted in thirty local government areas across the three selected North Central states of Kogi, Niger and FCT-Abuja; and other relevant secondary data obtained from various sources.

A representative sample of 600 respondents was planned for the survey in order to get at least 462 households responding, however, the study had 501 households responded representing about 84 per cent success rate.

Table 4.1. Socio-Economic characteristics of the respondents of the study area

\begin{tabular}{|c|c|c|c|c|c|c|}
\hline Study area & \multirow{2}{*}{\multicolumn{2}{|c|}{$\begin{array}{l}\text { Kogi } \\
36.73 \\
\end{array}$}} & \multirow{2}{*}{\multicolumn{2}{|c|}{$\begin{array}{l}\text { Niger } \\
36.13 \\
\end{array}$}} & \multicolumn{2}{|l|}{ Abuja } \\
\hline $\begin{array}{lll}\begin{array}{l}\text { Percentage } \\
\text { respondents }\end{array} & \text { distribution } & \text { of } \\
\end{array}$ & & & & & 27.15 & \\
\hline $\begin{array}{l}\text { Mean age of respondents by the } \\
\text { study area }\end{array}$ & \multicolumn{2}{|l|}{30.4} & \multicolumn{2}{|l|}{31.9} & \multicolumn{2}{|l|}{33.3} \\
\hline $\begin{array}{l}\text { Percentage distribution of } \\
\text { respondents with at least primary } \\
\text { school education }\end{array}$ & \multicolumn{2}{|l|}{16.9} & \multicolumn{2}{|l|}{25.9} & \multicolumn{2}{|l|}{18.1} \\
\hline Mean income per month(naira) & \multicolumn{2}{|c|}{$12,938.9$} & \multicolumn{2}{|c|}{$16,053.1$} & \multicolumn{2}{|l|}{8,028} \\
\hline $\begin{array}{l}\begin{array}{l}\text { Estimated average of } \\
\text { capital per month }\end{array} \\
\end{array}$ & \multicolumn{2}{|l|}{16,812} & \multicolumn{2}{|c|}{$22,534.2$} & \multicolumn{2}{|l|}{26,037} \\
\hline Occupation of Respondents & \multicolumn{2}{|l|}{$\begin{array}{l}\text { Farmers } \\
37.3 \%\end{array}$} & \multicolumn{2}{|c|}{$\begin{array}{l}\text { Civil Servants } \\
23.3 \%\end{array}$} & $\begin{array}{l}\text { Trading } \\
12.8 \%\end{array}$ & $\begin{array}{l}\text { Others } \\
26.4 \% \\
\end{array}$ \\
\hline \multirow{3}{*}{$\begin{array}{l}\text { Gender distribution of respondents } \\
\text { in the study area }\end{array}$} & Male & Female & Male & Female & Male & Female \\
\hline & 93 & 91 & 100 & 81 & 104 & 32 \\
\hline & $\begin{array}{l}\text { Total } \\
\text { male }=\end{array}$ & $\begin{array}{l}297 \\
(59.3 \%)\end{array}$ & & & $\begin{array}{l}\text { Total } \\
\text { female }=\end{array}$ & $\begin{array}{l}204 \\
(40.7 \%)\end{array}$ \\
\hline
\end{tabular}

Source: Field Survey, 2015

Table 4.1 indicates the socio-economic characteristics of the population of the area of study. It is of note that most of the respondents from the study area were between the mean age of 30,32 and 33 years respectively for the selected states, a category to which the core of the workforce is located. Most of them were married and heads of households.

The percentage distribution of respondents in the study areas shows almost an equal number of household responding from Kogi and Niger State with 36.73\% and 36.13\% respectively. However, FCT Abuja had only about 27.15\% of respondents. The skewedness of result can be explained by the size of the study area.

There was a substantial variation between male and female respondents. A total of $59.3 \%$ of the respondents were male while the female respondents were only $40.7 \%$. However, the skewedness of the respondent in favor of the male is attributed to the fact that among Muslim who constitutes greater percentage of the population in the state are married women who are usually prohibited from exposure to strange male research assistance based on religious belief.

The occupational characteristics of the population showed a predominance of farmers who constituted $37.3 \%$, closely followed by civil servant with 23.6\%, while others (Transportation, Traders, Petty Business Men and Women etc.) is $26.4 \%$. The average monthly income/wage of the respondent fell within the mean income or wage of $\$ 12,938.9, \$ 16$, 053.01 and $\$ 8,028.00$ respectively. While the estimated average of business capital per month shows $\$ 16,812.00$, $\$ 22,534.02$ and $\$ 26,037.00$ for Kogi, Niger and FCT respectively.

The percentage distribution of respondents with at least primary education shows that Kogi State 16.9\%, Niger 25.9\% and FCT $18.1 \%$. The implication of this is that, information dissemination to the people through print, electronic media might not have a serious problem in examining income inequality and poverty prevalence in the selected area. 
Table 4.2. Percentage distribution of manifestation of income inequality and poverty prevalence in Nigeria

\begin{tabular}{c|c|c|c}
\hline Variables & Yes & No & Total \\
\hline $\begin{array}{c}\text { Do you have any other support from financial institution other than } \\
\text { the source of your fund? }\end{array}$ & 28 & 72 & 100 \\
\hline Have you heard of income inequality before? & 80 & 20 & 100 \\
\hline Does your saving change directly with your income level? & 78 & 22 & 100 \\
\hline Do you think we have income inequality problem in Nigeria? & 68.9 & 31.1 & 100 \\
\hline $\begin{array}{c}\text { Does your present income level satisfactory with your current } \\
\text { expenditure level? }\end{array}$ & 20.2 & 79.8 & 100 \\
\hline $\begin{array}{c}\text { Do you have other source(s) of income augmenting your expenditure } \\
\text { level? }\end{array}$ & 34.1 & 65.9 & 100 \\
\hline $\begin{array}{c}\text { Has inadequate income level ever prevented you from accessing the } \\
\text { basic primary health care delivery in your locality? }\end{array}$ & 80 & 20 & 100 \\
\hline $\begin{array}{c}\text { Do you think that income inequality is a major determinant of } \\
\text { poverty in Nigeria? }\end{array}$ & 84 & 16 & 100 \\
\hline \begin{tabular}{c} 
In your view, where do you think poverty occurs most in Nigeria? \\
\cline { 1 - 3 } Is government doing enough to reduce poverty in Nigeria?
\end{tabular} & Rural area & $\begin{array}{c}\text { Urban } \\
\text { area }\end{array}$ & \multirow{2}{*}{100} \\
\hline
\end{tabular}

Source: Field survey; 2015

From the table 4.2 above, 80 percent of the respondents have heard about income inequality. The table reveals more households are vulnerable to poverty at rural than in the urban centers in the study areas. The result shows that 76percent of the residents vulnerable to poverty in the rural area while 24percent in urban areas. More so, about 68.9 percent of the respondents' acknowledged income inequality as a current problem in Nigeria while 31 percent disagreed. Only 33percent believed that government is doing enough to curtail this menace.A good number of the responding households (66percent) were believed not to have any other source of income with its adverse effect on their ability to save from the meager income they earn.The table 4.2 above indicates that most of the capitals operated by the respondents are from their personal savings, income from friends and other informal financial institutions such as: Adashi, Osusu. More so, 78 percent agreed that their savings change directly with their income level. Furthermore, greater number of respondents, 80 percent agreed that their income level has prevented them to accessing the basic primary healthcare in their locality. This is a manifestation of poverty prevalence in the rural areas.

\subsection{Presentation of Regression Results}

Table 4.3. Summary of the Stationarity test result on the variables used in the analysis

\begin{tabular}{|c|c|c|c|c|c|c|c|c|}
\hline \multirow[t]{2}{*}{ Variables } & \multirow{2}{*}{$\begin{array}{l}\text { Test } \\
\text { statistic }\end{array}$} & \multicolumn{3}{|l|}{ At level } & \multicolumn{3}{|c|}{ At first diff. } & \multirow[t]{2}{*}{ Remarks } \\
\hline & & Intercept & $\begin{array}{l}\text { Intercept } \\
\& \text { trend }\end{array}$ & None & Intercept & $\begin{array}{l}\text { Intercept } \\
\& \text { trend }\end{array}$ & None & \\
\hline \multirow{2}{*}{ PCI } & $\mathrm{ADF}$ & $-4.39 *$ & $-4.60 * *$ & $-2.91 * * *$ & $-11.44 *$ & $-14.43 *$ & $-14.76^{*}$ & \multirow{2}{*}{ Sig. @level } \\
\hline & PP & $-4.66^{*}$ & $-4.60 *$ & $2.91 * * *$ & $-14.76^{*}$ & $-16.44 *$ & $-14.76^{*}$ & \\
\hline \multirow{2}{*}{ RDIFF } & $\mathrm{ADF}$ & $-4.51 *$ & -2.08 & -2.77 & $-6.93 *$ & $-7.38^{*}$ & $-7.02 *$ & \\
\hline & $\mathrm{PP}$ & -2.85 & -1.68 & -0.34 & $-8.50 *$ & $-8.26^{*}$ & $-8.62^{*}$ & \\
\hline \multirow{2}{*}{ Depratio } & $\mathrm{ADF}$ & $4.01 *$ & -1.24 & 2.01 & $-8.07 *$ & $-8.61 *$ & $-7.45^{*}$ & \\
\hline & $\mathrm{PP}$ & 3.01 & -2.66 & 1.38 & $-10.89 *$ & $-16.39 *$ & $-9.22 *$ & \\
\hline \multirow{2}{*}{ GPCf } & $\mathrm{ADF}$ & -2.31 & -2.21 & -0.46 & $-3.88^{*}$ & $-3.68 *$ & $-5.54 *$ & \\
\hline & PP & -2.45 & -2.37 & -0.44 & $-3.46^{*}$ & $-4.42 *$ & $-5.54 *$ & \\
\hline \multirow{2}{*}{ EDU } & ADF & -1.68 & -0.33 & -0.62 & $-4.16^{*}$ & $-4.78^{*}$ & $-4.39 *$ & \\
\hline & PP & -1.65 & -0.62 & $\begin{array}{l}-0.71 \\
\end{array}$ & $-4.40 *$ & $-4.78 *$ & $-4.41 *$ & \\
\hline \multirow[b]{2}{*}{ CAL } & $\mathrm{ADF}$ & -2.35 & -2.29 & -0.06 & $-6.92 *$ & $-6.99 *$ & $-7.03 *$ & \\
\hline & $\mathrm{PP}$ & -2.31 & -2.17 & -0.25 & $-8.76^{*}$ & $-8.86^{*}$ & $-8.86^{*}$ & \\
\hline \multirow[b]{2}{*}{ PHc } & $\mathrm{ADF}$ & -2.35 & -2.79 & -1.06 & $-3.51 *$ & $-3.68 *$ & $-5.54^{*}$ & \\
\hline & PP & -2.84 & -1.98 & -1.34 & $-2.45^{*}$ & $-2.37 *$ & $-0.44 *$ & \\
\hline \multirow{2}{*}{ Resid01 } & $\mathrm{ADF}$ & $-8.55^{*}$ & $-6.11 *$ & $-6.21 *$ & $-6.11 *$ & $-6.07 *$ & $-6.24 *$ & \\
\hline & PP & $-6.83 *$ & $-6.76^{*}$ & $-6.90 *$ & $-15.82 *$ & $-15.54 *$ & $-17.14 *$ & \\
\hline
\end{tabular}

Source:Obtained by the Author from the Analysis; 2015 
Key:*=significant @1percent; **=significant @ 5percent and ***=significant @10percent, Critical values below are those significant @ intercept only at both test tools (ADF and PP). Note: The residual was integrated of order I (0); as such the model was co-integrated at level accordingly.

From the results of the stationarity test on the variables used in table 4.3 above, it was found that per capita income (PCI), relative income difference (RDIFF), and dependency ratio (Depratio) were stationary at level of intercept, intercept \& trend and none respectively while the rest variables such as: gross fixed per capita formation (GPCf), Education (EDU), Calorie intake (CAL) and poverty head count (PHc) were accordingly differenced once I (0).

Table 4.4. Summary of the Results of the estimated Model

\begin{tabular}{|c|c|c|c|c|}
\hline \multicolumn{5}{|c|}{ Results of the estimated Model } \\
\hline \multicolumn{5}{|c|}{$\begin{array}{cc}\text { Estimated Model } & \left(\mathrm{PCI}=\sigma_{1}+\sigma_{2} \operatorname{sincQ}_{1} \mathrm{Q}_{4 \mathrm{it}}+\sigma_{3} \mathrm{PCI}_{\mathrm{t}-1}+\varepsilon ; \text { where } \Delta \mathrm{incQ}_{1} \mathrm{Q}_{4 \mathrm{it}}=\beta_{1}+\beta_{2} \text { depratio }+\beta_{3} \mathrm{GPCf}+\right. \\
\left.\mathrm{GPCf}_{\mathrm{t}-1}+\beta \mathrm{Edu}+\beta \mathrm{Cal}+\beta \mathrm{Phc}+\varepsilon\right)\end{array}$} \\
\hline \multirow{2}{*}{\multicolumn{2}{|c|}{ Method: Two stage least squares estimation: }} & \multicolumn{2}{|c|}{$\begin{array}{l}\text { Breusch-Godfrey Serial } \\
\text { Correlation LM Test }\end{array}$} & \multirow{2}{*}{$\begin{array}{c}\text { Prob. F(2,34) } 0.0134 \\
\text { Prob. Chi-Square(2) } \\
0.0169\end{array}$} \\
\hline & & Obs*R-squared & 8.166565 & \\
\hline Variable & Model & P-values & & \\
\hline Constant & $-4.82 \mathrm{E}+11$ & 0.2276 & & \\
\hline RDIFF & -18.21576 & 0.0022 & & \\
\hline $\mathrm{PCI}_{\mathrm{t}-1}$ & 0.269055 & 0.0350 & & \\
\hline Adjusted R2 & 0.637706 & - & & \\
\hline F-statistic & 9.0009 & - & & \\
\hline F-probability value & 0.00116 & - & & \\
\hline Data scope: $1991-2013$ & 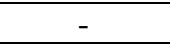 & - & & \\
\hline Instrument rank & 8 & - & & \\
\hline DW statistic & 2.112409 & - & & \\
\hline J-statistics & 5.9769 & - & & \\
\hline Prob(J-statistics) & 0.03084 & & & \\
\hline SE of the regressed result & $5.82 \mathrm{E}+10$ & - & & \\
\hline
\end{tabular}

Source: computed by the author from the analysis; 2015

\subsection{Analysis of Results and Discussions of Findings}

\subsubsection{Discussion of Result fom the secondary data}

From the results above, given that the adjusted $\mathrm{R}^{2}$ and F-Statistics are 0.637706 and $9.0009(\mathrm{p}$-value $=0.00116)$ respectively; it follows that at least one of the variables in the model explains the variation on the explained variable, per capita income (PCI) by at least 64 percent. This implies that 63.7percent of dependent variable is explained by the independent variables. This implied that 36.3 percent of the dependent variable is not explained by the independent variables but been affected by other factors outside our study. This means it is a good fit and statistically significant at 1 percent.

Both the regressors (RDIFF and PCI) in the model, the regress and (PCI) are in log form. The model was exactly identified (see Gujarati, 1995). Given that both the relative income differences and lagged value of per capita income were statistically significant; therefore, a percent (1percent) increase in relative income differences (RDIFF) would lead to a significant reduction per capita income of the households by 18.22 percent holding other factors constant. (See table 4.4). On the other hand, a percent rise in lag value of per capita income (PCIt-1) would lead to a significant increase in per capita income of household by 0.27 percent ceteris paribus. (See table 4.4).

The implication of the result first is that the distributive growth in per capita output (income) before now has been largely skewed; secondly, the result further shows that dependency ratio, level of calorie intake, poverty per head count are all together significant factors influencing the level of (or prevalence) poverty. Lastly and expectedly, the expected a priori signs were in order amongst the estimated variables thrown in the analysis.

\subsubsection{Summary of Major Findings}

From the result, it can be concluded that high prevalence rate of poverty in conjunction with income inequality no doubt has greatly affected the development of human capital in North Central and Nigeria in general.

The study obviously found a causal relationship between relative income difference (RDIFF) and per capita income (PCI) a proxy of poverty. The study also found that 64 percent of dependent variable is explained by the independent variables. Both the relative income differences and lagged value of per capita income (PCIt-1) were statistically significant a 1 percent increase in relative income differences (RDIFF) would lead to a significant reduction of per 
capita income of households by 18.22 percent. This can be linked to growing dimension of poverty. Given the result in table 4.2, it is seen that 84 percent of the respondent agreed that inequality in income is a significant determinants of poverty prevalence in North Central states and in Nigeria in general.

The study found a considerable level of poverty prevalence in North Central States. For instance the lagged value of per capita income was significant and would relatively increase poverty prevalence up to 27 percent on average. In addition, the study found a high prevalence of poverty in rural area up to 76 percent (see table 4.2). This is also in line with multidimensional poverty index report of 2010 which shows that 46 percent Nigerian live below the National poverty line with only 28 percent in urban areas and nearly 70 percent in rural areas.

Furthermore, the study found that Gross per capita formation, level of education among households, level of calorie intake and poverty head count to be functional to relative difference in income which all together factors affecting per capita income a measure of poverty prevalence. It was found that relative difference in income (RDIFF) of the quintiles was significant and capable of declining PCI by about 18 percent and hence, growth in the North Central States.

\section{Conclusion and Recommendations}

Increasing income inequality and poverty continue to be the most challenging economic problem facing most developing countries and Nigeria is not an exception.

Poverty has remained a major source of concern to many developing nations of the world because of its debilitating effects on citizenry. In Nigeria poverty is multi-faceted and it incorporates economic, social, cultural and political dimensions. As such achieving an appreciable rate of poverty reduction through equitable income distribution within a reasonable time requires commitments of both government and society in general.

It was found that the level of calorie intake and per capita income formation have to a large extent depended on the level of relative income differences amongst income groups. Finally, education is seen as key to reducing poverty incidence in Nigeria.

Arising from the preceding empirical findings, the following policy implications can be deduced.

i. The study found income inequality significant; as a result, reducing inequality in income level amongst groups should be a deliberate policy to reducing incidence of poverty in Nigeria especially amongst the rural dwellers. Government should give subsidies and credit facilities to farmers, artisans and traders through cooperative organizations, specialized agencies and micro finance houses in order to step up their incomes. Government should also increase it expenditure in social services, promote employment opportunities and encourage labour augmenting technical change. Beside government at all level should ensure more equitable distribution of income and an acceptable revenue sharing formula.

ii. The study established that since calorie intake and capital formation depend largely on income differences, government should devise ingenious way(s) of having to intervene either directly or indirectly by improving the nutritional intake of rural dwellers particularly farmers, traders and artisans and enhance their earnings power to help build their human capital. Government should reasonably step up expenditure in both social service and health sector with a view to enhance growth of domestic economy and alleviate the impact of poverty.

iii. More so, there is need to overhaul existing poverty alleviation programmes, so that they are strengthened to make the desire impact. In addition, there is need to campaign against large family size, while women are placed on birth control to reduce dependency ratio especially in rural areas.

iv. Quality education is seen as key to eradicating inequality in income and in turn high incidence of poverty in Nigeria. Government should increase it expenditure on education with a view of reducing the high literacy level in line with the Millennium Development Goals (MDGs). Efforts should be made to fund and re-position the tertiary institutions with a view of making graduates self employed rather than seeking for jobs after graduation. There is need for instituting good governance in every sphere of government activity which is a sine-qua-non for poverty reduction.

v. In all, greater efforts should be made towards strengthening the domestic macro economic growth in the economy. This is complemented by relevant policies aimed at addressing equitable distribution of income among various groups and sectors.

\section{References}

Akeredolu, A. E. O. (1975). Poverty as a social issue: A theoretical note in poverty in Nigeria, O, Teriba (ed), The Nigerian Economic Society, Ibadan

Atoloye, A. S. F. (1997). Strategy for Growth led Poverty Alleviation in Nigeria, Nigeria Economic Society's Annual 
Conference Proceedings, Ibadan, 569-585.

Awe, A. A., \& Olawumi, O. R. (2012). Determinants of Income Distribution in the Nigeria Economy: 1977-2005 Canadian Research \& Development Centre of Sciences and Cultures Address: 9375 Rue de Roissy rossard, Québec, J4X 3A1, Canada

Babatunde, R. O. (2008). Income Inequality in Rural Nigeria: Evidence from Farming Household Survey Data, Australian Journal of Basic and Applied Sciences, 2(1), 134 - 140.

Balogun, E. D. (1999). Analyzing Poverty Concepts and Methods. CBN. Bullion, 23(4).

Bello, A. M. (2007). The activities of the Agency paper achieved at a two-day capacity building workshop on the Theme - Child Trafficking and Child Labour: Organized by Nigerian Agency for Prohibition of Trafficking in persons and other related matters (NSPTIP), Kano, May.

Birdsall, S. N. (2005) Raising Inequality in the New Global Economy. World Institute for Development Economic Research (WIDER) Angle, 2(1).

Bourguignon, F., Fournier, M., \& Gurgand, M. (1998). Distribution, development and education: Taiwan, 1979 - 1974. World Bank, Mimeo.

Chou, Y. (1969). Statistical Analysis $1^{\text {st }}$ Edition, New York: Holt, Rinehartend Winston.

Dalton, H. (1920). The measurement of inequality of incomes. The Economics Journal, 30. https://doi.org/10.2307/2223525

Englama, A., \& Bamidele, A. (1997). Measurement Issues in Poverty Alleviation in Nigeria, a Selected Papers for the 1997 Annual Conference of the Nigerian Economic Society.

Haralambos, M., \& Heald, R. M. (1980). Sociology: Themes and perspectives. New York. Oxford University Press.

Huppi, M., \& Ravallion, M. (1990). The Sectoral Structure of Poverty during an Adjustment Period: Evidence from Indonesia in the mild - 1980's" World Bank PRE Working Paper 529, Washington, D.C.

Igbatayo, S. A., \& Igbinedion, S. O. (2006). The Challenges of Poverty Reduction in Sub - Sharan African Experience. Journal of Business Administration and Management. 1(1), 35.

Ilori, B. (1999). Policies and Measures for Poverty Alleviation CBNBullion 23, Now.

Kolenikov, S., \& Shorrocks, A. (2003). A Decomposition Analysis of Regional Poverty in Russia.Discussion Paper No. 2003/74. World Institute for Development Economic Research (UNU/WIDER), Helsinki.

Kuper, A., \& Kuper, J. (Eds). (1996). The social science encyclopedia. New York; Routledge.

Litchfield, J. A. (1999). Inequality Methods and Tools, Text for World Bank's Site on Inequality, Poverty and Socio-economic Performance. www.worldbank.org.

Muhammad, A. (2014). Level of Poverty in Nigeria: 247 U-reports impartial observers, Abuja, Nigeria.

Nigeria Bureau of Statistics (NBS). (2010). Nigerian Poverty Profile Report, January 2010. Abuja: NBS.

Nweze, N. J., \& Ojowu, O. (2002). Poverty, well-being and wealth generation in Benue State. Unpublished material.

O’Donnel, M. (1997), Introduction to sociology United Kingdom Thomas Nelson and Son Ltd.

Obansa, S. A. J. (2011). Economics of Onchocerciasis control in Nigeria, The FCT in focus. Pg. 62.

Oladunni, E. B. I. (1999). The dimensions of poverty in Nigeria: Spartial, sectoral and gender. Central Bank of Nigeria Economic and Financial Review, 39(4), 23-30.

Oyekale, A. S. (2005). Sources of Isncome Inequality and Poverty in Rural and Urban Nigeria. Journal of Development Economics, 51, 267-290.

Pigou, A. F. (1912). Wealthy and Welfare London Macmillan Press.

Ravallion, M., Anand, S., \& Wang, O. J. (2009). Human Development in Poor Countries: On the Role of Private Incomes and Public Services. Journal of Economic Perspectives, winter, 2009.

Sachs, J. (2005). The End of Poverty, How We Can Make it Happen in Our Lifetime. Penguin Press, London

Soludo, C. C. (2006). Can Nigeria Be the China of Africa? Being a lecture Delivered at the Founder's Day of the University of Benin, Nigeria, 23, pp. 10.

Tella, S. A. (1997). A scheme for monitoring poverty alleviation. "Nigeria Economic Society" Annual Conference proceedings, Ibadan, $73-83$. 
Ugoh, S., \& Ukpere, W. (2009). Appraising the Trend on Poverty Alleviation Programmes in Nigeria with Emphasis on the National Poverty Eradication Programme (NAPEP). Business Papers and Reports 2009, Cape Peninsula University of Technology, Cape Peninsula South Africa.

United Nations Development Programme (UNDP). (1990). Human Development Report: New York Oxford University Press.

United Nations Economic Commission for Africa. (UNECA) (2005). Economic report on Africa: Meeting the challenges of unemployment and poverty in Africa Addis Ababa, Ethiopia, 41-98.

UNU/WIDER. (2000). United Nations University/ World Institute for Development Economic Research, World Inequality Database, Vol. 10, Helsinki.

Walpole, E. R. (1974). Introduction to Statistics Published by Macmillan/McGraw-Hill

World Bank. (1993). Poverty Reduction Handbook. The World Bank, Washing D,C.

World Bank. (1996). Taking Action to Reduce Poverty on Sub - Saharan Africa: An Overview Washington, D.C., 2-3.

\section{Copyrights}

Copyright for this article is retained by the author(s), with first publication rights granted to the journal.

This is an open-access article distributed under the terms and conditions of the Creative Commons Attribution license which permits unrestricted use, distribution, and reproduction in any medium, provided the original work is properly cited. 